\title{
Indian Topic in R. Kipling's early Creative Art («Plain Tales from the Hills», 1888): An Alternative View

\author{
Olga Posudiyevska
}

\author{
Department of Foreign Languages for Engineering, Technical and Natural Sciences, \\ Oles' Honchar Dnipropetrovsk National University, Ukraine \\ anlang@ukr.net
}

Keywords: jingo-imperialistic position, civilizing mission, exotic space, motherland, Anglo-Indian unity, own/alien environment, tolerance to the «alien»

\begin{abstract}
This article presents the study of Rudyard Kipling's early pieces of writing (the collection of stories Plain Tales from the Hills, 1888). The author proposes an alternative view to the consideration of the writer's literary heritage from the position of jingoism and propagation of the civilizing mission of the British Empire, which can still be encountered in academic research. The analysis of Plain Tales from the Hills suggests that the praise of British imperialism was not the main idea of Kipling's early works. The researcher comes to the conclusion that Kipling did not regard India as a conquered barbarous land which the British people had to civilize. This remote exotic country became a motherland for a representative of Anglo-Indian society, who was born in Indian environment. Kipling's love for India is felt in his strive to give a detailed description of exotic locations and ethnographic peculiarities and even to restore the manner of speech of Indian population. The reader of Plain Tales from the Hills can perceive the author's respect for the English and Indian people, working in harsh climate, his interest and great sympathy with the aboriginal population, living in hard social conditions under the British rule. The sarcastic remarks of his characters, which reflect Kipling's doubt in the beneficial role of the British Empire in the lives of the Indian people, finally refute the statement about the writer's glorification of the imperialistic policy of Great Britain as the main aim of his creative art.
\end{abstract}

\section{Introduction}

December, 30, 2015 and January, 18, 2016 are Rudyard Kipling's anniversary dates (150 years since the writer's day of birth and 80 years since his death). Therefore, it is not surprising that nowadays the interest to the biography and creative art of the youngest Nobel Prize winner in literature has increased manifold. During 2015-2016 a great number of articles were published in English media (the Telegraph, the Tribune). Newcastle University organized a Special Collections exhibition in February, 2016. Kipling's rich heritage is commemorated by festivals, readings, conferences (annual festival in Rottingdean; conference Rudyard Kipling and Europe, University of Bologna; Kipling readings, Mumbai; conference Kipling in India: India in Kipling, Simla).

During the centennial period the literary heritage of the author of Kim and The Jungle Book was appreciated differently - often negatively, mainly because of the writer's imperialistic appeals. Kipling was «our first authority on the second-rate» (Oscar Wilde [15, p. 1012]) and «the brightest representative of that England which...presses the whole world for the sake of her fame, wealth and might» (Alexander Kuprin [9, p. 609]), a «very talented writer», but with a «harmful propagation of imperialism» (Maxim Gorky [2, p. 155] and «a jingo imperialist...morally insensitive and aesthetically disgusting» (George Orwell [11]). As Jaime Weinman notes, Kipling had the popularity of a rock-star, which faded just after the celebrity's demise, as «...in 1936...he was considered not only old-fashioned, but a representative of British imperialism at its most unthinking» [14].

However, despite all jingo-imperialistic accusations, it is obvious that Kipling's literary heritage has survived the test of time. Nowadays Kipling is considered as one of the most wellknown English writers of the end of the XIX century and the bright representative of 
neoromanticism. One of the possible reasons of the author's never-ceasing popularity is Kipling's ability to depict the Indian world from inside - mostly not from the position of a conqueror, who came to invade a rich, barbarous land, but from the point of view of the representative of AngloIndian society, for whom India became a mother country.

\section{Discussion}

The articles on Kipling often emphasize the fact that he is one of the most oft-quoted authors of English literature and is even cited by people who didn't read his pieces of art. However, it does not seem surprising, as, according to the researchers' fair remarks, the author's ability «to choose the most substantial events» from «first-hand observations of the surroundings» was reflected in the «compression of ideas into compact, resonant phrases», many of which were even transformed into proverbs (e.g. «East is East, and West is West, and never the twain shall meet») [13, p. 53; 14].

Laconic manner of narration and witty words are characteristic features of Kipling's creative art, starting from early works - «sometimes wry, sometimes tragic stories» [10], resembling newspaper reports, which appeared for the first time on the pages of The Civil and Military Gazette (where the author worked simultaneously as a reporter and an assistant of the editor-in-chief) and then were collected into a book (Plain Tales from the Hills, 1888).

Literary critics often assess negatively these pieces of writing «about the idiosyncrasies of British India and the uneasy relationship between rulers and ruled» - «painfully Anglo-Indian» stories with the «lack of freshness and enthusiasm», which can be hard for comprehension, as the author strives to omit the analysis of his characters' states of mind and depicts only the result of their internal struggle $[10 ; 12 ; 14]$. As the scholars claim, the stories create a bright image of an exotic country in the shine of its imperialism, but living there results in a cultural decay for an Englishman $[10 ; 12]$. However, it should be noted that Kipling's concerns about the decrease in the level of cultural intelligence of the Anglo-Indians, in comparison with the standard of culture, typical of the Victorian society, became a popular problem of his early writing. Thus, the ironic sketch Anglo-Indian society (1887), written in the form of a letter of an English tourist, travelling across India, reveals typical features of worldview and lifestyle of British colonists who started losing cultural bonds with their historical motherland and tried to find their place in a new AngloIndian society. Kipling uses a traditional image of a traveler from far off in order to demonstrate more convincingly the advantages and drawbacks of Anglo-Indian mentality, showing them through the point of view of an outsider who has leaved India and is «now beyond the reach of vengeance» [3]. For the British tourist (whose image, in fact, conceals in itself the author's personality) the life of Englishmen in India is plain and lacks the smallest possibility of cultural entertainment, as work is the only aim of existence for them: «Every one...talks and thinks about his work...they are enthusiastic enough about their work - always their work», so «...they don't seem to realize any of the beauties of life - perhaps they haven't time» [3].

As Kipling admitted in his autobiography, only «picked men at their definite work» could survive in India - «Civilians, Army, Education, Canals, Forestry, Engineering, Irrigation, Railways, Doctors, and Lawyers» [6]. The representatives of these professions - the «picked», ready to work hard 10-15 hours a day in a hot and humid climate and to die from lethal diseases for the sake of a great imperialist mission, - mainly become the characters of Plain Tales from the Hills. However, it should be noted that the choice of characters, plot events and the range of problems in the stories do not seem to prove that the author's only aim was to show the shine of imperialism and exoticism and, thus, to approve in literary way «the civilizing mission of Great Britain», as some scholars tend to claim [16, p. 152].

Undoubtedly, in some episodes of the stories it looks as if the writer tries to emphasize the civilizing role of the Englishmen who «die...kill themselves by overwork... are worried to death or broken in health and hope», trying to protect the wild land «from death and sickness, famine and war» (On the city wall [5]). The Indian «savages», on the contrary, perform very low quality of work: «everything here is raw, unfinished, misjointed, slack and wrongly built» [3], as the native «have been playing with English machinery and type» [3] However, the author's irony, felt in every 
observation of such type, shows that Kipling does not try in reality to stress the advantage of the Englishmen over Indian population. The observation that «if an advance be made» due to the work of British colonists, in any case «all credit is given to the native» becomes the culminating point of the writer's irony [5].

In fact, Kipling in his stories perceives other aims, apart from describing in humorous way the episodes from Anglo-Indians' lives and their relationship with the local population. As the researchers aptly note, the characters' destinies «are inscribed into the life itself with its hardships, famine, losses, illnesses, heat, natural disasters and all possible misfortunes which...should be overcome», and the external «harmless» form of the narrative suddenly turns into "acidulous and sarcastic» criticism of policy of the ruling class, contradicting completely to the concept of British «civilizing mission» [13, p. 59, 60; 16, p. 157]. Instead of the chauvinistic pathos, in the majority of stories the author expresses genuine admiration for mental strength and firmness of people who work in harsh climate conditions (At the End of the Passage [4]). The reader can feel Kipling's respect for the Indian culture and lifestyle and whole-heartedly sympathize, along with the author, with the main character of The House of Suddhoo who «...sleeps on the roof generally, except when he sleeps in the street» [7], and with the fate of an Indian girl, whose mother sold her to an Englishman, as they were living on the breadline (Without Benefit of Clergy [8]). Kipling's question, voiced by his hero in At the End of the Passage, sounds poignantly sarcastic: what can «the Civil Service in India...the pet preserve... of the aristocracy of England...get from that country, which we have step by step fraudulently annexed?» [4]. The further comment becomes even more unpatriotic: the members of British government in India avoid the tasks, concerning the policy of ruling the country, and «...force the unhappy peasant to pay with the sweat of his brow for all the luxuries in which they are lapped» [4].

\section{Conclusion}

It is likely that Kipling, having acquired education in the home country, was inclined to believe in a special civilizing mission of the British colonists. On the other hand, the writer himself was a descendant of the «wild» environment which the British Empire was supposed to civilize. A barbarous country for the civilized Victorians became Kipling's motherland, which he loved. Unlike the Englishmen living in Foggy Albion, the representative of Anglo-Indian society could perceive through his own experience the problems of encounter of completely different worldviews, social and moral values and lifestyles. This perception intensified to the greatest extent during the period of the writer's living in India after the return from Great Britain (1882-1889), which was the time of creation of Plain Tales from the Hills. Unsurprisingly, the civilized English community in the author's early works is closely connected with the aboriginal world, thus forming a single Anglo-Indian unity. Kipling strives to describe in exact details the locations, ethnographic features and peculiarities of behavior, as well as to introduce speech patterns of his characters. In this way, the episodes of life of the British colonists are depicted on the exotic Indian background. As the scholars justly note, the writer tries to reproduce even the «sounds and smells of India that he had fallen in love with as a child» [1] (it should be noted that even the first childhood memories of the writer are associated with «...daybreak, light and colour and golden and purple fruits at the level of my shoulder» [6]).

Although the author strives to create the illusion of authenticity of depicted events, the «real» India from his works becomes a remote exotic space where Kipling checks the validity of high spiritual values and moral ideals - love, friendship, devotion to duty and tolerance to the «alien». The writer raises the eternal life problems, which are actual for the humanity at all stages of its development. Thus, the range of the author's ideas is much broader than just an attempt to affirm a jingo-imperialistic position. After reading Kipling's early works it becomes evident that the praise of jingoism is not the main message of the writer of Anglo-Indian origin, narrating about his own environment. 


\section{References}

[1] 150th Anniversary of the birth of Rudyard Kipling, Available:

https://blogs.ncl.ac.uk/speccoll/2015/12/30/150th-anniversary-of-rudyard-kipling/, 30 Dec. 2015.

[2] M. Gorky, The collected works: in 30 volumes, Moscow, USSR, 1953, Vol. 24, p. 66 (in Russian).

[3] R. Kipling, Anglo-Indian society, on: http://www.kiplingsociety.co.uk/rg_sketches_36.htm.

[4] R. Kipling, At the end of the passage. Available: http://www.telelib.com/authors/K/KiplingRudyard/prose/LifesHandicap/endpassage.html.

[5] R. Kipling, On the city wall, on: http://www.online-literature.com/kipling/indian-tales/13/.

[6] R. Kipling, Something of myself for my friends known and unknown. Available: http://gutenberg.net.au/ebooks04/0400691.txt.

[7] R. Kipling, The house of Suddhoo. Available: https://ebooks.adelaide.edu.au/k/kipling/rudyard/plain/chapter17.html, 27 Mar. 2016.

[8] R. Kipling, Without benefit of clergy. Available: https://archive.org/stream/withoutbenefitc00kiplgoog/withoutbenefitc00kiplgoog_djvu.txt.

[9] A. Kuprin, The collected works: in 6 volumes, Moscow, 1958, Vol. 6, p. 609 (in Russian).

[10] S. McClarence, Rudyard Kipling's India. Available: http://www.telegraph.co.uk/travel/destinations/asia/india/articles/Rudyard-Kiplings-India/, 30 Dec. 2015.

[11] G. Orwell, Rudyard Kipling, on: http://orwell.ru/library/reviews/kipling/english/e_rkip.

[12] Rudyard Kipling. Exceedingly popular stories. Available: https://www.theguardian.com/books/2002/oct/12/featuresreviews.guardianreview1, 06 Jan. 2016.

[13] F.M. Skliar, Kipling - short-story writer: from report to story, Problems of World Literature. Collection of scientific papers, Tashkent, USSR, Vol. 603, 1979, pp. 53-63 (in Russian).

[14] J. Weinman, Why does Rudyard Kipling get no respect? Available: http://www.macleans.ca/society/why-does-rudyard-kipling-get-no-respect/, 08 Dec 2015

[15] O. Wilde, The Collected Works: The Plays, the Poems, the Stories and the Essays including De Profundis, Hertfordshire: Wordsworth Editions Ltd., 1997, pp. 963-1016.

[16] L. Zotova, Conceptual, philosophical and aesthetical components of neo-romantic method in R. Kipling's early creative art, Collection of Materials of International Scientific and Practical Videoconference "Philology, Art and Cultural Studies: Actual Problems and Tendencies of Development", Novosibirsk, Russia, 2013, pp. 151-158 (in Russian). 